\title{
Open Issues at the Conclusion of Privatization (Corporate Ownership Restructuring) in Slovenia - Comment and Views
}

Danijel Pucko*

The influence of privatization of former state (self-managed) enterprises in Slovenia on their competitive position and financial performance is the core issue dealt with in the article.

The analysis performed by CEEPN shows some first perceived influences which are evidently different in the enterprises with the prevailing internal ownership (employees are their dominant owners) from those which are present in the enterprises with the prevailing external owners. (The corpus of enterprises analyzed is unclear in the article - but I believe that it includes 787 enterprises with the prevailing internal ownership and 346 enterprises with the prevailing external ownership what makes the total number of 1133 enterprises analyzed.)

It is not against expectations that (according to the analytical findings) the enterprises with the prevailing external ownership have achieved better financial results (i. e. net income). An internal owner - employee has interest in a relatively higher wage and therefore a relatively lowere financial result of the enterprise. This is the way how less net income is distributed to external owners. No doubt there appears the question if it is aproper behavior that will provide for the enterprise's existence and development in the long run?

One should not be surprised at the findings that enterprises with dominant external ownership have decreased the level of their indebtedness. As the interest rates in the country have been higher than the level of profitability of the companies, any decreasement of the debts has normally contributed to better financial results.

One can wonder why the enterprises with the prevailing external ownership have invested more in their fixed assets and why they grow faster than the other group of enterprises. My hypothesis is that employees-owners do not see themselves as enterprise owners in the long run. The logical consequence is their inclination to increase the indebtedness of the enterprise, disinvestments, management substitutions in case that top management makes decisions which are not in

\footnotetext{
* Danijel Pucko, University of Ljubljana, Slovenia
} 
accordance with the interest of internal owners etc. Such explanation is supported by a few perceived facts from my field research work in Slovenia. One can find internal "stock exchanges" organized nearly in all enterprises with the prevailing internal ownership. Such an institution is not usually present in the enterprises with dominant external owners.

The process of ownership concentration of the enterprises with the prevailing internal ownership is going on with assistance of such internal "stock exchanges". The stocks of enterprises with the prevailing internal ownership are not usually traded on public stock exchanges yet. These enterprises do not intend to come with their stocks to the public stock exchange before the year 2,000 . Top managers report that there is much more tension in the supervisory boards'decision making between the representatives of internal and external owners than in the enterprises with the prevailing external ownership.

In my opinion one can expect faster strategic restructuring of the enterprises that have dominant share of external ownership. The other group of enterprises will need more time for their advancing through the phase of revival towards the phase of renewed successful financial performance. I do not believe that the entry of strategic partners or bankruptcy are the only strategic options for the latter group of firms. Many options will be implemented. The domestic takeovers could be already well perceived as one of them. My own research findings ${ }^{2}$ show that the strategic restructuring process of "old" Slovenian enterprises (those that already existed in the socialist era) have advanced in a positive direction. There were $17.2 \%$ of manufacturing enterprises in the crisis situation in the beginning of 1994 and only $6.8 \%$ in the beginning of 1996 . The satisfaction with the profit achieved in the enterprises also improved in 1996 in comparison with 1994. The profitability level achieved in enterprises was higher in 1995 than in 1993. It can not be argued that those achievements are there just because of the enterprises with the dominant external ownership.

Not only leadership styles but the whole management process should be considered as being in some phase of "searching". In previous Yugoslavia participative decision-making within the framework of workers' selfmanagement was present. Today one can argue that the "natural reaction" happened. Many strong tendencies to implement autocrate leadership style are present in Slovenian enterprises. Numerous elements of organizational culture in enterprises which are still strongly rooted in the workers selfmanagement system do not permit for an autocratic leadership style to perform well. Frequent indications that internal information and communication systems in enterprises are not adequate are noticed in my field research work. These signals are just one strong warning that a proper management system that will take into account

${ }^{2}$ See Pucko D., (1996) Characteristics of Strategic Restructuring Processes in Slovenian Enterprises, (1996): Slovenska ekonomska revija, Vol. 47, No.5-6, p.477 
the wholeness of cultural background of the region is still to be developed in Slovenian enterprises. 